\title{
APRECIACIÓN FÍLMICA DE STEVEN SPIELBERG POR PARTE DE LA RECEPCIÓN
}

\section{STEVEN SPIELBERG FILM APPRECIATION BY THE RECEPTION}

Beatriz Peña Acuña: Universidad San Antonio. Murcia (España)

beatriz-pa@gmail.com

\section{CURRÍCULUM VITAE}

Licenciada en Filología, Diplomada en Humanidades y Periodista. Profesora de "Observación sistemática y análisis de contextos" en Magisterio Infantil, "Trabajo fin de Grado" en Turismo y "Comunicación interna" a posgrados. Profesora del Cuerpo de Tutores de la Universidad Católica San Antonio. Ha participado en diversos congresos internacionales de innovación educativa como International Conference of Education and Innovation e International Technology, Education and Development Conference con varias ponencias en inglés y ha publicado artículos concernientes a la educación en vasrias revistas científicas. Ha publicado material para docentes de Secundaria para la editorial on-line de Santillana: profes.net. Ha publicado un manual sobre "Métodos de observación aplicados a las Ciencias Sociales y la Educación" dirigido a alumnos de Magisterio.

\section{RESUMEN}

Esta investigación pretende tomar una muestra de espectadores y críticos de una página de base de datos sobre la cinematografía, IMBD, que consta de un apartado de crítica y opinión para realizar un análisis sobre la conciencia del espectador en cinco aspectos: la dignidad humana, la ética, la emoción, el héroe y Steven Spielberg. 
Se tendrá como referencia también la aceptación de estas películas tomando como referencia el éxito que obtuvieron en taquilla.

\section{PALABRAS CLAVE}

Steven Spielberg - Taquilla - Emoción - Dignidad Humana - Héroe

\section{ABSTRACT}

This research aims to take a sample of viewers and critics of a database page on the film, IMBD, which consists of a section of criticism and review for analysis on the spectator's consciousness in five areas: human dignity, ethics, emotion, the hero and Steven Spielberg. It will also reference the acceptance of these films reference to the box office success obtained.

\section{KEY WORDS}

Steven Spielberg - Taquilla - Emoción - Dignidad Humana - Héroe

\section{ÍNDICE}

1. Muestra de espectadores

2. Muestra de críticos

3. Recaudación de taquilla

4. Bibliografía

5. Apéndice

Anexo I

I.1.- Clasificación de los comentarios de espectadores en IMBD

I.2.- Clasificación de los comentarios de los críticos en IMBD 
Anexo II: Lista de presupuesto y recaudación de taquilla de la filmografía spielbergiana

TEXTO:

\section{ANÁLISIS SOBRE CUATRO PELÍCULAS DE STEVEN SPIELBERG}

Esta investigación pretende tomar una muestra de espectadores y críticos de una página de base de datos sobre la cinematografía (IMBD)[1], que consta de un apartado de crítica y opinión para realizar un análisis sobre la conciencia del espectador en cinco aspectos: la dignidad humana, la ética, la emoción, el héroe y Steven Spielberg. Se tendrá como referencia también la aceptación de estas películas tomando como referencia el éxito que obtuvieron en taquilla[2]

\section{Muestra de espectadores}

Se empezará por la muestra de espectadores de la página web Imbd (on-line) sobre cuatro películas: A.I., Inteligencia Artificial, Minority Report, Atrápame si puedes y la Terminal. El estudio observa cuarenta comentarios en inglés por parte de usuarios de cada película, en total 160 comentarios. Esta página web es idónea porque cuenta con un número extenso de comentarios. La metodología ha consistido primero en aislar aquellos fragmentos tantos favorables como desfavorables sobre la dignidad y la emoción para detectar la percepción del receptor sobre estos dos aspectos. Se realiza un cómputo comparativo para evaluar qué aspectos son de interés para el receptor. Un segundo factor de análisis, consistirá en contabilizar cuántos de estos comentarios se refieren al protagonista para descubrir la atención del receptor sobre el héroe. Un tercer factor será tener en cuenta cuántos comentarios 
han sido positivos y cuántos negativos para evaluar un nivel perceptivo negativo o positivo del espectador sobre el cineasta o su película.

Los datos que se extraen de este análisis son los siguientes. Se comienza por exponer datos sobre los comentarios de los espectadores que permita sacar alguna conclusión indicativa. Los comentarios sobre la temática en relación a la dignidad son en total 66. Con planteamiento ético directo o con un juicio directo son $38 / 66$, cifra que supone un $575 \%$. Con aplicación directa a la realidad norteamericana cinco comentarios sobre sesenta y seis, un 7`5\%.

El promedio de comentarios por persona teniendo en cuenta que la muestra estaba formada por 40 personas es de $1^{\prime} 6$ comentario por persona. Si se realiza una comparación entre el número de comentarios temáticos y la emoción, se llega a la afirmación de que la emoción consta de 22 comentarios, cifra que supone un $32{ }^{`} \%$. Destaca la emoción que dicen experimentar a través de la interpretación de algún actor con 10 comentarios sobre 22 , lo que supone un $45^{\prime} 4 \%$.

Los comentarios sobre el héroe por orden de mayor a menor comentario son $63 \% 2 \%$ en La terminal, 58`3\% en Atrápame si puedes, 39\% en Inteligencia Artificial y 30`4\% en Minority Report. El promedio de aparición del héroe en estas películas es del $47^{\prime} 2 \%$. Las palabras con más número de aparición son personaje(s) (18 veces), emoción (11), humano u hombre (9), moral (7), Spielberg (4), valor (2).

Los comentarios negativos sobre las películas son reducidos, son cuatro sobre cuarenta, es decir, un 10\% de los comentarios de la muestra son negativos. En cuanto a la valoración de los espectadores sobre las películas se presenta por orden de mayor estimación que corresponde al orden de aparición de cartelera: A.I., Inteligencia Artificial recibe tres comentarios negativos sobre diez, y una puntuación de un 93/100; Minority Report no recibe comentario negativo y una puntuación de 
87/100; Atrápame si puedes recibe un comentario negativo sobre diez y una puntuación de 81`4/100; La Terminal no recibe ningún comentario negativo y una puntuación de 80`5/100.

\section{Muestra de críticos}

También esta investigación considera una segunda muestra de recepción de las cuatro películas estudiadas según una muestra de diez comentarios de críticos de películas de revistas de cine en Internet también tomados de la base de datos de Imbd. Suman un total de cuarenta comentarios tanto en castellano como en inglés.

La muestra que se ha tomado de cuarenta comentarios plantea noventa comentarios sobre la dignidad, con un promedio de 2’2 comentarios temáticos, y con tendencia a comentar contenido con implicación ética de un 72׳2\%. Esto muestra un incremento interesante respecto al estudio de la muestra anterior, lo que puede indicar en los críticos una mayor sensibilidad hacia temas humanos y éticos.

Otro dato significativo ha sido encontrar que el promedio de comentarios temáticos sobre el héroe ha sido de un 58'8 \%, destacando el caso de Frank Abagnale Jr., el estafador, con un $37^{\prime} 7 \%$ de los comentarios temáticos, y David, el pequeño robot, con un $24^{\prime} 4 \%$. Los comentarios sobre el héroe son mayores en esta muestra. Se descubre que Frank es el protagonista con más comentarios en las dos muestras.

Es interesante descubrir que sólo un $11 \%$ de los comentarios se refieran a la emoción, cifra que es menor ostensiblemente respecto a la anterior muestra porque se trataba de un tercio. Por otro lado, de estos comentarios sólo un $23 \%$ se han referido explícitamente a haberlo obtenido a través de la interpretación o caracterización de algún personaje, mientras en la anterior muestra se trataba de la mitad. 
Las palabras con mayor aparición en los comentarios nos parece también indicativo con el predominio de la palabra personaje(s) (15), emoción (29) y hombre (o humano) (32). Con menor participación aparece moral (9) y con discreción la palabra valor (1). La proporción de esta muestra contempla un aumento llamativo en dos palabras "emoción" y "hombre" respecto a la anterior muestra. Sobre el término Spielberg contemplado como índice de otros agentes, hemos encontrado que aparece 50 veces. Este hecho puede mostrar la mayor concienciación por parte de los críticos de la autoría del cineasta sobre el film. Asimismo se confirma la preocupación explícita sobre temas humanos (antropológicos) y morales también con el factor de mayor aparición de palabras en los comentarios.

Respecto a la actitud de la audiencia con las cuatro películas se considera en esta investigación que han sido muy bien acogidas y valoradas por los críticos pues, predominan los comentarios positivos frente a los negativos (82 frente a 48). Si se compara con la anterior muestra en la que los espectadores realizaron 14 comentarios negativos, se puede pensar que los comentaristas han sido mucho más críticos con Spielberg y se han atenido más a detalles concretos.

\section{Recaudación en taquilla}

Sobre la apreciación fílmica de estas cuatro películas por parte de la recepción teniendo en cuenta la recaudación de taquilla en EE.UU., se anotarán varias observaciones después de cierto análisis.

Spielberg casi siempre ha sacado beneficio por encima del presupuesto en el grueso de recaudación menos en tres ocasiones: El imperio del sol (1987), A. I., Inteligencia Artificial (2001) y Munich (2006). 
Este cineasta en varias ocasiones ha multiplicado el presupuesto. Este estudio clasifica tres estadios de éxito: la primera, donde supera hasta tres veces el presupuesto, la segunda, hasta seis y la tercera, lo multiplica más de diez veces:

por dos Loca evasión (1974), La guerra de los Mundos (2005)

por tres La lista de Schindler (1993), El mundo perdido: Parque Jurásico (1993), Salvar al soldado Ryan (1998), Atrápame si puedes (2002)

por cuatro Indiana Jones y la última cruzada (1989); por cinco Parque Jurásico (1993);

por seis Encuentros en la tercera fase (1977), Indiana Jones y el templo maldito (1984), El color púrpura (1985)

por más de diez Tiburón (1975), En busca del Arca perdida (1981), E.T. el extraterrestre (1982) son las más acogidas por la taquilla con una recaudación multimillonaria.

Se trata de un director muy exitoso en audiencia, pues de 24 películas, 14 han multiplicado el presupuesto. Si consideramos las películas con mayor recaudación multimillonaria se trató del comienzo de su carrera (1975-1982), en 1993 tiene otro hito con Parque Jurásico, y vuelve a llamar la atención con Atrápame si puedes (2002).

Se observa que han sido han sido mucho menos consideradas por la recepción estas cuatro películas de madurez. Sólo una película de las cuatro estudiadas, Atrápame si puedes, ha supuesto para él un triunfo en el primer rango de éxito que hemos 
considerado. Otra victoria en nivel menor también lo ha conseguido La guerra de los Mundos (2005).

Volver a la recaudación en taquilla Volver al principio del articulo Volver al comienzo

\section{Bibliografía}

Bibliografía genérica

BAXTER, J., Steven Spielberg The unauthorised biography, London, HarperCollins 1996

CALDEVILLA DOMÍNGUEZ, David, El estilema de autor en Steven Spielberg: un sello personal en lo audiovisual, tesis, Universidad Complutense de Madrid, Facultad de Ciencias de la Información, Departamento de Comunicación Audiovisual y Publicidad II), Madrid, Manuscrito inédito, 2000

CALDEVILLA DOMÍNGUEZ, D., El sello Spielberg, Vision Net, Madrid, 2005

DEPUYDT, X., Approche tematiche de Spielberg, Bruxelles, 1993

DE CILLIA, M., Steven Spielberg au carrefour de l’image, Université de Nice, 1988

FRIEDMAN L.D. y NOTBOHM B. (ed.) Steven Spielberg interviews, University Press of Missisippi, 2000

MCBRIDE, J., Steven Spielberg a biography, London, Faber and Faber, 1997 
SÁNCHEZ ESCALONILLA GARCÍA-RICO, A., La infancia como constante y su evolución en la obra cinematográfica de Steven Spielberg, Universidad Complutense de Madrid, 1995

TIMCHIA TUBUO, Ernest, The moral content of the major works of Steven Spielberg: a theological analysis, Pars dissertationis, ed. Universidad Lateranense, Academia Alfonsiana, Institutum Superius Theologiae Moralis, Roma, 2003

TIMCHIA TUBUO, E., The moral content of the major works of Steven Spielberg: a theological analysis, Dissertatio, ed. Universidad Lateranense, Academia Alfonsiana, Institutum Superius Theologiae Moralis, Roma, Manuscrito inédito, 2003

\section{$\underline{\text { Webgrafía }}$}

www.labutaca.net/films/5/ai5.html [acc: 25.IX.2006]

www.labutaca.net/films/11/minorityreport13.htm [acc: 25.IX.2006]

www.labutaca.net/films/14/atrapamesipuedes6.htm [acc: 25.IX.2006]

www.labutaca.net/films/25/theterminal5.htm [acc: 25.IX.2006]

www.fotograma.com/notas/reviews/1697.shtml [acc: 25.IX.2006]

www.fotogramas.orange.es/fotogramas/CRITICAS/8438@CRITICAS@0.html [acc: 25.IX.2006]

www.film.guardian.co.uk/Film_Page/0,4061,444413,00.html [acc: 25.IX.2006]

www. film.guardian.co.uk/Film_Page/0,4061,716851,00.html [acc: 25.IX.2006]

www.film.guardian.co.uk/Film_Page/0,4061,1290758,00.html [acc: 25.IX.2006]

www.rogerebert.suntimes.com/apps/pbcs.dll/article?AID=/20010629/REVIEWS/1

06290301/1023 [acc: 25.IX.2006]

www.variety.com/review $/$ VE1117798324? categoryid=31\&cs $=1 \& s=h \& p=0 \quad$ [acc:

25.IX.2006] 
www.variety.com/ac2005_review/VE1117924107?nav=reviews\&categoryid=1798\&c $\mathrm{s}=1 \& \mathrm{~s}=\mathrm{h} \& \mathrm{p}=0$ [acc: $25 . I X .2006$ ] www.urbancinefile.com.au/home/view.asp?a=5255\&s=Reviews [acc: 25.IX.2006] www.urbancinefile.com.au/home/view.asp?a=6951\&s=Reviews[acc: 25.IX.2006] www.reelviews.net/movies/m/minority_report.html [acc: 25.IX.2006] www.reelviews.net/movies/t/terminal2004.html [acc: 25.IX.2006] www.slate.com/id/2067225 [acc: 25.IX.2006] www.slate.com/id/2102591 [acc: 25.IX.2006] www.bbc.co.uk/films/2002/06/24/minority_report_2002_review.shtml [acc: 25.IX.2007] www.eye.net/eye/issue/issue_12.19.02/film/onscreen.html [acc:25.IX.2006] www.dir.salon.com/story/ent/movies/review/2002/12/25/catch_me/index.html? $C P=I M D \& D N=110$ [acc: 25.IX.2006] www.washingtonpost.com/ac2/wp-dyn/ A39990-2002Dec26 [acc: 25.IX.2006] www.officecom.qc.ca/Media-film/Fiche/Catchmeifyoucan.html [acc: 25.IX.2006] www.cine.ciberanika.com/cri28.htm [acc: 25.IX.2006] www.timesonline.co.uk/article/0,7943-1242329,00.html [acc: 25.IX.2007] www.reel.com/movie.asp?MID=139060\&buy=closed\&Tab=reviews\&CID=13\#tabs [acc: 25.IX.2006] www.sfgate.com/cgi-bin/article.cgi?f=/c/a/2004/06/18/DDGKE779LG1.DTL [acc: 25.IX.2006] www.citypaper.net/articles/2004-06-17/movies.shtml [acc: 25.IX.2006] www.us.imdb.com/title/tt0212720/usercomments [acc: 25.IX.2006] www.us.imdb.com/title/tt0181689/usercomments [acc: 25.IX.2006] www.us.imdb.com/title/tt0264464/usercomments [acc: 25.IX.2006] www.us.imdb.com/title/tt0362227/usercomments [acc: 25.IX.2006] Volver a la bibliografía Volver al principio del articulo Volver al comienzo 


\section{Apéndice}

\section{$\underline{\text { Anexo I }}$}

I.1.- Clasificación de los comentarios de espectadores en IMB

A. I. Inteligencia Artificial (2001)

Comentarios sobre temática (con relación a la dignidad) (13)

- A robot child's interaction within a family, and the second deals with the robot's estrangement from its family and the quest to regain the mother's love

- Spielberg, never comfortable with sexual material

- It raises some interesting and sometimes unsettling moral dilemmas that few films of late have done.

- Like all intelligent science fiction, such as Kubrick's own 2001: A SPACE ODYSSEY and Spielberg's own CLOSE ENCOUNTERS, A.I. forces us to ponder where we've been and where we might be going.

- I could also see the sensitivity that Spielberg added to scenes and characters.

- In A.I., there is never a question of David being human: he is nothing but a machine that smartly apes a real loving boy. 
- The boy robot has a chip or whatever it is that programs him to feel 'love,' being such 'love,' if correctly interpreted (something the movie does not do), not real love, but an unhealthy fixation.

- It wants to be profound and philosophical (we know that because from time to time some character, or the voiceover narration, says something sententious).

- it's what drew them both to "A.I." Pinocchio, the Blue Fairy, cuddly Teddy Bears on one hand, but on the other hand - social institutions are faltering forever -parenthood, childhood, science, industry, sexuality -- all distorted beyond repair.

- And Humans, the ultimate A.I. protagonist, seem blissed-out, in denial, more interested in creating "Davids", "Darlenes" and "Gigolo Joes" than in rising water levels and the imminent threat of extinction.

- AI could have been a thought-provoking movie about the moral dilemma of programming robots to think, feel physical pain and experience human emotion, but not giving them the same rights as living individuals.

- The already too-long movie did not benefit from that ridiculous Spielberg ending where Aliens (of course!) come and rescue David and Teddy from the ocean floor, to reveal that it is possible to give life to his mother (from DNA from a clipping of her hair) but that she would only last one day.

- Despite the fact that it was cut hair, and you need the hair root to clone from

Comentarios con referencia a la emoción (10)

- Steven Spielberg's emotionally harrowing epic about a robot boy 
- It still leaves us with an open, startled emotional disorientation

- "AI" is a very personal film, a deeply moving

- It will effect your emotions

- It's an incredible combination of Kubrick's icy intellectual and clinical mind and Spielberg's emotional heart.

- By the sickening sentimentality that clogs the whole movie and reaches its peak in the completely stupid ending.

- Was this added on to be a genuinely heartfelt moment where all of David's sadness and tears are alleviated.

- emotional story of a child's quest for maternal love.

- This blend allows the emotional story of a young robotic boy to come to life

- The Kubrickian style demands the very best from actors, who must appear unapologetically real, and must, in long sequences with no dialogue, convey strong feelings and emotions. The A.I cast, especially lead actor Haley Joel Osment, meet every measure of the demands

Comentarios en referencia al héroe (9/23), es decir, sobre un 39\% de los comentarios están referidos al protagonista.

Comentarios negativos $(3 / 10)$ 
Minority Report (2002)

Comentarios sobre temática (con relación a la dignidad) (20)

- Anderton must unravel the mystery of why he has to murder a man whom he hasn't even met yet

- The content is amazing - all the little details that put the audience firmly in the middle of the 21st century. The lives of everyday people in the film, where they are scanned and advertised 'at' all day every day.

- A world where 'they' know your every move (a future towards which we are already hurtling with some speed).

- And it asks the kind of questions about morality, justice, exploitation and society that'll keep you thinking for much longer that the film's two and some hours.

- It is simply a entertaining and yet realistic glimpse of what our future may look like, as advertising becomes more advanced and intrusive.

- The film creates many moral questions and issues, and should leave you thinking.

- in Minority Report by a drug-dealer on the streets with no eyes at all, so I suppose its free advice for John Anderton, our hero, or a bit of wise-sounding advice meant to get across to the audience but with no other good place for it to fit in the film 
- John Anderton is similar to noir's morally ambiguous characters--a good cop with an illegal habit that is forced (by circumstances and desire) to betray the very things he loves.

- As always, Max von Sydow authoritatively plays the respected father figure.

- The future, we are told, are what we make of it.

- The system, of course, raises civil liberty issues, but seems to work perfectly, that is until Anderton is fingered for a murder.

- it's easy to manipulate us into thinking the future is a grim place, if you pushprocess the film until even the images which in the normal course of events would be luscious and rich, are grimy and desaturated

- how much freedom we are willing to give up in exchange for safety (in order to prevent terrorist attacks, for instance).

- Three people (the precogs) do indeed give up their freedom in order that millions of other people may be safer, and yes, there is an issue here.

- When one of the Crime Prevention officer says, "It's best not to think of them as human", I was surprised to find myself nodding in agreement. The benefits of the system are so great that OF COURSE I'd rather not look too closely into the burden that must be borne by three - just three - individuals.

- The interesting issues that DO fall naturally out of the story concern the futility of revenge. 
- however much it may be in the interests of justice, serves no purpose

- It's exacting revenge on criminals for the sake of exacting revenge - which is exactly what the U.S. justice system is committed to doing at the moment, which is why the future is a realistic one.

- Anderton's mistake is to believe in the value of revenge, and he's never more admirable than when he realises his mistake.

- Parents, a note: if your child is under 12 at least I would strongly recommend you watch this film first. It's dark, compelling, and disturbing- particularly in a scene where he has to exchange his eyes for protection...

Comentarios con referencia a la emoción (3)

- Agatha. Who saw the film and didn't share her terror and vulnerability? Little touches such as the way she clings to Cruise, almost like a baby's reflex, make her a character you immediately care about

- (Anderton) by the way he sits or walks, we can intuit the grief and confusion that's going through him

- The blueish tint given to the film also gives us a cold feeling, a future that is not as loving or as hospitable as the time we live in, another trait of a Dick story.

Comentarios en referencia al héroe $(7 / 23)$

Comentarios negativos $(0 / 10)$ 
Atrápame si puedes (2002)

Comentarios sobre temática (con relación a la dignidad) (7)

- The interaction between these two characters (FBI agent and Frank Jr.) was great, it was interesting to see a budding relationship slowly build between two characters who were actually positioned against one another.

- However, the film is rife with moral ambiguity.

- the film never really focuses on the morally bankrupt side of the story.

- Spielberg was interested in the Frank Abagnale character because as a youngster he also came from a broken family and wanted to be someone else. Spielberg would sneak onto the studios and tell people that he worked there.

- Frank, on the run, actually starts to become friends with Hanratty, who realizes Frank is just an adolescent and does not realize the eventual outcomes of what he is doing. Hanratty sort of adopts Frank

- Christopher Walken is Great as Frank's father. You could tell immediately Frank was influenced by him.

- The surprise was the unique relationship of the FBI agent and the con-man in their cat-and-mouse chase they have over the years around the globe.

Comentarios con referencia a la emoción (5)

- A thoroughly absorbing and worthwhile picture. 
- the plot is fascinating and keeps you laughing, crying and wondering until the end.

- Christopher Walken gives one of his best performances in his already interesting career. The last scene of him as he talks to his son in the restaurant is so moving that it reflects on the great talent of Walken. You can understand why Dicaprio admires and loves his father. Walken conveys these emotions and makes the audience react just accurately.

- it isn't always as light-hearted as the film is.

- The strange but enjoyable chemistry between these two characters goes a long way toward making this movie work.

Comentarios en referencia al héroe $(7 / 12)$

Comentarios negativos $(1 / 10)$

La terminal (2004)

Comentarios sobre temática (con relación a la dignidad) (26)

- I don't like the claustrophobic movies where the fun has been made of the characters who are awkward foreigners that can not speak English.

- film starts to look at that man closer and finds a lot in him to admire.

- The most important for me was the part when we finally find out why Victor Navarsky (Tom Hanks), the citizen of the fictitious Eastern European Country Krakozia came to New York City 
- Stanley Tucci's character was such a great idea. It is not exactly clear why he is determined to make Victor's life even more confusing and miserable with the tenacity deserving better purpose

- to make a hero and saint of Hanks' character, either

- I have to say it is a great one that first shows the meaning and beauty in our life about waiting and promise

- He has done everything for others around him. If there is a great example of "egoless", he is one

- for people living in this country busy around everyday for business, families, and so on, to slow down and reflect on something.

- Hanks sees more of America than he could have ever imagined

- he constantly has trouble with airport supervisor Stanley Tucci

- Runway worker Diego Luna makes a deal with Hanks so he can learn about passport officer Zoe Saldana

- Hanks meets an elderly Indian janitor

- Hanks falls in love with 30-something flight attendant Catherine Zeta-Jones (perfectly illuminating and beautiful as usual).

- I'd call this mostly a heartwarming and completely absorbing character study of one man's attempt to make a life for himself in an airport terminal. 
- A movie about characters, not plot.

- shy but proper food delivery person and the immigration official better. Navorski was kind gentle and wise as acting as their Cyrano.

- She knows Navorski's value. She knows his character and how good he is. She wants him and is certain he wants and deserves her,

- wonderful character study well worth seeing

- Based on the true story of Viktor Navorski (Hanks;in his impressive role as an illegal alien) who gets stuck in an airport in New York and can't risk to step a foot out in N.Y without being arrested.

- Viktor survives, learns English by himself, makes new friends among the employees of the airport and falls in love for Amelia Warren (Catherine Zeta-Jones).

- "The Terminal" is a delightful and uncommon fable about a patient man who is trapped by the bureaucracy in the international lounge of JFK. I heard that an equivalent event

- The character of Victor Narvorski is one of those classic movie characters who has no conceivable flaw (other than a minimal understanding of the world around him and an accent) and dose everything he can to help everyone else.

- Some of these friends include Airport worker Enrique Cruz (Diego Luna), who Victor helps get hitched with a beautiful security guard (Zoë Saldana) and Amelia Warren (Catherine Zeta-Jones) a nice, flighty flight attendant who Narvorski inspires to get out of a troubled relationship with a married man 
- The Hanks and Zeta-Jones characters strike up a little romance

- It takes sometime but soon Narvorski is accepted into a small group of Airport workers including Cruz, kindly Joe Mulroy (Chi McBride) and janitor Gupta Raja (Kumar Pallana), who at first thinks that Narvorski is a federal agent out to get him.

- Dixon is not a villain. As it's established in the beginning, Dixon has been working the same job at the airport for seventeen years and wants desperately to climb up the latter

- The acting in this movie is the greatest factor

Comentarios con referencia a la emoción (4)

- he story behind his arrival is simple, sweet, and touching

- About emotion, not CGI.

- The film suffered a little from becoming a bit over emotional, the love story seemed out of sorts and the way the entire airport staff seemed to know every thing about everyone else

- is that Victor is an honest man, and he will obey the rules and stay in the terminal until he's allowed to leave

Comentarios en referencia al héroe (19/31)

Comentarios negativos $(10 / 10)$ 
I.2.-Análisis y clasificación de los comentarios de los críticos: a continuación se expone los comentarios de diez críticos on- line por cada una de las cuatro películas.

\section{A.I. Inteligencia Artificial}

Comentarios con relación a la dignidad de la persona (32)

- Spielberg, más dado a llevar a la pantalla historias con moraleja, y moraleja positiva

- se enfrenta a las situaciones más reales y cotidianas de un matrimonio que necesita sustituir su objeto de afecto, y como genera en ellos un dilema moral.

- introduce cuestiones éticas y morales acerca del amor y las responsabilidades que puede tener un humano hacia un robot

- recoge una cierta reivindicación en torno a temas raciales o de discriminación ante estos seres artificiales diferentes

- nos enfrenta al problema de la identidad y la individualidad de un niño que quiere ser a la vez igual que los humanos que le rodean,

- A.I. plantea una ambiciosa cuestión filosófica y moral que queda desdibujada en su desarrollo y finalmente irresuelta

- Por eso resulta difícil reconocer como auténtico amor a este apego artificial 
- En A.I., tenemos a tres personajes androides con diferente nivel de concienciación acerca de su naturaleza,

- Gigolo Joe, a pesar de su apariencia frívola, es consciente de su papel en el mundo, la forma en que asume su condición, y su resignada lealtad hacia David, acaba siendo la actitud más inteligente y conmovedora de todas.

- repasa humanísticas cuestiones como la sensibilidad, la familia, la maldad, los sueños, el progreso y los límites -si es que existen- entre el hombre y la máquina

- Amo y señor del mundo, el hombre, junto a su aliada la ciencia, ya ha diseñado objetos para satisfacer todas las necesidades cotidianas habidas y por haber

- hay algo que aún no se ha inventado: una máquina que sea capaz de dar amor.

- la película me pareció una rebuscada metáfora del esclavismo y racismo,

- A diferencia de otros films de ciencia ficción de corte futurista, en "A.I." hay una mirada optimista en cuanto al futuro

- la humanidad está diezmada psicológicamente por el control de natalidad impuesto por la autoridad: las familias no pueden tener todos los hijos que quisieran

- Mónica activa el "amor" de David al leerle unas palabras en voz alta. La lengua es un motor de vida, como lo puede ser insuflar aire en los pulmones.

- David y Gigolo Joe se amaparan en la solidaridad entre perseguidos frente a la barbarie étnica 
- Lo único que puede salvarlos a ambos es la clemencia de un niño que surte efecto en una madre.

- Why not manufacture a robot child that can love and so bring big bucks consolation to barren or bereaved mums and dads?

- Yet you can't help wondering why all this fuss about robots that love matters so much.

- What responsibility does a human have to a robot that genuinely loves?

- Do our human feelings for him make him human?

- It involves man's relationship to those tools that so closely mirror our own desires that we confuse them with flesh and blood

- We are in the future; global warming has drowned the world's coastlines, but the American economy has survived, thanks to its exploitation of mechas. "I propose that we build a robot that can love,"

- Spielberg explores the paradoxes that result, as David wins their love and yet is never--quite--a real boy

- It's here that "A.I." moves into its most visionary and problematical material

- touches upon such matters as what it means to be a human being, the definition of family and the notion of creation in both scientific and religious terms 
- A genius professor named Hobby (William HurtWilliam Hurt) announces to colleagues his intention to build a child robot that can dream and have a subconscious and an emotional life.

- summons up questions of the definition of humanity,

- human beings could represent just one stage in the evolutionary life cycle, a stage that at a certain point was rendered obsolete

- human resourcefulness is in full flight, engineering ways of coping with everyday life with the help of robots

Comentarios sobre la emoción (21)

- nítidas emociones

- uno de los artistas que mejor ha sabido transmitir las emociones humanas en la pantalla

- ¿Por qué hay gente, pues, que tiene miedo a dejar bullir sus emociones?.

- el generoso sentimentalismo de Spielberg

- y la forma en que manipula las emociones

- Este sentimentalismo acentuado que tiñe de melodrama todas sus cintas se ha convertido en una marca de la casa, una seña de identidad que hace reconocibles sus trabajos. 
- desde la emotividad gastada y la magia infantil de Spielberg, que fuerza al espectador a la lástima, y que es contraproducente

- Sus emociones ciegan su parte más racional, pero tratándose de una máquina deberíamos decir más bien que ha sido programado específicamente para que su inteligencia emocional y su capacidad de metacognición sean mínimas,

- trata de un niño robot, llamado David (Haley Joel Osment), quien es creado con un simulador de emociones

- No quiero contar nada más para no arruinar la diestra manipulación de emociones a la que nos sujeta Spielberg

- "Inteligencia Artificial" es una película de difícil compenetración emocional por parte del público.

- la mamá de David, logra los picos emocionales que le exige el papel sin perder credibilidad, mostrando a la vez conmovedora vulnerabilidad y férrea fuerza en sus instintos maternales

- construye un ser a su imagen y semejanza pero superior en lealtades, afectos o buenos sentimientos

- un robot de la edad de un niño que pueda expresar emociones y sentimientos "naturalmente", que pueda amar "realmente"

- componentes finales para un desconcertante y emotivo final, escrito y dirigido por el nunca bien amado, pero previsible, Steven Spielberg 
- Is it a feeling, a root emotion, a nifty bit of computer wiring?

- it miscalculates in asking us to invest our emotions in a character that is, after all, a machine

- We are expert at projecting human emotions into non-human subjects, from animals to clouds to computer games, but the emotions reside only in our minds

- Spielberg concentrates with intense focus on the gradual accrual of emotions, themes and motifs having to do with the ties that bind and don't.

- Brakes have been put on what might have been sentimentalized or emotionally milked situations.

- Osment again proves himself a superb young actor, not emoting in obvious fashion but strongly holding centerscreen for nearly 2-1/2 hours. Other perfs are serviceably low-key, with Law doing a lively if limited turn as a peacock among robots and O'Connor registering most of the story's most explicit emotions.

Comentarios con referencia al héroe (16)

- Creación de David, un niño robot capaz de amar pero que no puede huir de su condición de máquina

- A partir de aquí, la película explica la extenuante búsqueda por parte de David del Hada Azul, personaje de Pinocho que cree lo transformará en humano.

- David trata de delimitar su propia identidad, manteniendo ese difícil equilibrio entre la igualdad -la escena de las espinacas- y la diferencia respecto a los otros 
- Sufre los mismos problemas de identidad y afecto que su niño androide protagonista.

- Haley Joel Osment, repasa humanísticas cuestiones como la sensibilidad, la familia, la maldad, los sueños, el progreso y los límites -si es que existen- entre el hombre y la máquina

- comienza su angustiante búsqueda de un hada madrina que, como a Pinocho, pueda convertirlo en un niño de verdad para poder reconquistar así el cariño materno.

- he has an advanced chip that allows him to learn, adapt and "love," when Monica permanently "imprints" him.

- David, gracias a un avanzado chip, desarrolla sentimientos y conciencia, lo cual altera profundamente la actitud de sus padres

- David is treated with cruelty by other kids; humans are frequently violent and resentful against mechas.

- Haley Joel Osment está, sencillamente, genial; sólo hay que ver su rostro para darnos cuenta del terror que siente al percatarse de que ya no va a volver a ver a su madre nunca más

- Quien en algún momento dirigiera la impactante "Tiburón", cree en la idea de golpear y humillar para que el factor "Bambi" (o "El Rey León") haga lo suyo.

- En este punto la obsesión edípica del pequeño robot se apodera de la narración. 
- David, a mecha who looks as lifelike and lovable as--well,

- Osment, who is onscreen in almost every scene, is one of the best actors now working

- a boy robot who can be programmed to bond with his parents, love his mother and love her forever

- David soon learns - through a wild adventure in the company of robotic Gigolo Joe (Jude Law) - that humans and robots are on different sides

Comentarios negativos (21) frente positivos (13)

- la película es un proyecto fallido porque Spielberg no es el director adecuado para él.

- unos treinta minutos llenos de infantilismo y fantasía

- una película de sólidos pensamientos

- hasta cierto punto, Spielberg ha hecho un enorme esfuerzo de contención a lo largo de la película para no caer en su fatídica tendencia a la lágrima fácil

- A.I. a nivel narrativo y conceptual donde resulta más inconsistente, pretenciosa e insípida.

- el film acaba reduciéndose a un diálogo consigo mismo en el que la autocompasión y la autocomplacencia rezuman por igual 
- A.I. es un producto más artificial que inteligente; no consigue ser la gran película que pretendió y se pierde en su propio mar de dudas.

- Stanley Kubrick y que su amigo, el gran Steven Spielberg, logró llevar a la pantalla grande, no pudo estar ni cerca de la talla de muchas de las obras con las que ambos directores ya se aseguraron un inmortal lugar en la historia del cine.

- la cinta deambula sin encontrar nunca su mejor ritmo ni su fluidez, y sin poder acaparar definitivamente la atención a través de sus escasos picos de intensidad.

- la película con la cual Spielberg quería rendir homenaje a Kubrick -había sido él quien alguna vez le había comentado la idea de hacerla-, no termina siendo más que un discreto y a veces aburrido entretenimiento

- Sólo permite recordar la invisible presencia del director de La naranja mecánica en pequeños instantes conceptuales, los mejores del filme, en los que puede respirarse la espesa atmósfera de su cine.

- Las escenas en la "Feria de la Carne" deben ser las peores del film. Absolutamente ridículas y desmotivadas.

- Spielberg no encuentra nada mejor que citarse a sí mismo y da un salto en la narración que dura alrededor de 2000 años.

- the writing falls notably short is in the brief opening and, especially, closing narration, which would have benefited from a more exalted and poetic touch.

- It is, uniquely, a total wreck. 
- Pero quien logre tragar esos torpes finales

- su peor defecto es pretender ser el director que no es, fingiendo creer en ese costado pseudo-filosófico sin tener la capacidad siquiera para escribir un buen guión de ficción.

- A.I. fails to generate the level of emotions their robotic boy is supposed to display

- the script suffer from verylongitis, schmalz and sentimentality, it lacks the inventiveness and sharpness that the subject matters demands

- This kind of carelessness - and predictability - don't belong in a film that aspires to tell a story of great relevance and magnitude

- these thrills are small compensation for the overall disappointment the film generates

Comentarios positivos (13)

- Si a nivel técnico A.I. ha sido desarrollada de forma más o menos digna,

- También es de agradecer que por una vez los efectos especiales estén al servicio de la historia y no viceversa

- Otro punto a favor de la película son los efectos especiales. Estamos muy acostumbrados a ver buenos efectos; lo que no es tan común es la imaginación del diseño y la innovación técnica y conceptual que muestra la película 
- Encontrará una inteligente película de Ciencia Ficción (no ópera espacial ni aventuras futuristas) que propone ideas y conceptos poco vistos en el cine, con la característica vehemencia de Spielberg y su acostumbrado experto manejo del aspecto técnico.

- Su mejor cualidad es dirigir actores (aunque suene tautológico),

- At least he sets himself daunting challenges. At least - at 53 - he is still exploring the boundaries of a formidable talent

- What is beyond question is that Spielberg is a much more mature filmmaker than he was 20 years ago

- Much of the film's astonishment, then, resides in the way it almost exponentially grows in impressiveness from one stage to the next

- this issue is incidental to his having proved himself up to the task of taking on subjects of this magnitude and making them dramatically absorbing

- Special visual effects and animation by Industrial Light \& Magic, with credit going most prominently to Michael Lantieri, Dennis Muren and Scott Farrar, as well as Stan Winston's robot character design and animatronics, are top of the line

- Yet there are redeeming aspects, including Frances $\mathrm{O}^{\prime}$ Connor as the mum, who stays natural (in both looks and character) and William Hurt in a couple of short but effective scenes

- if you can lower your expectations, you will find parts of it interesting, if nothing more 
Minority Report

Comentarios con relación a la dignidad de la persona (25)

- the vast encroachments of technology surrendered to for good and ill, changing the way people live but not noticeably altering the quality of life.

- it is more prosaic than poetic, more concerned with narrative progress, precise predictions and legalistic issues than larger notions of good and evil, fate and the grand scheme of things

- The theological note intriguingly struck by Witwer early on is unfortunately never sounded again, and while the film's rootedness in a future "reality" is compelling

- the vast encroachments of technology surrendered to for good and ill, changing the way people live but not noticeably altering the quality of life.

- The theological note intriguingly struck by Witwer early on is unfortunately never sounded again

- They all stop for a few seconds to allow these tiny instruments of the state to zap them in the eyeball, then carry on with their activity, a detail suggesting just how everyday an occurrence this has become. Nobody, however, is having any fun

- Predestination or free will? It's a question that has obsessed philosophers and religious scholars throughout the years. Now, it is the underlying subject material of a major motion picture not for deep thinkers but for a mass audience 
- The prediction drives the act - a self-fulfilling prophmotion picture made not for deep thinkers but for a mass audience

- Then there are the moral and ethical considerations to explore. Is the safety and security of the populace worth keeping three human beings enslaved? And are people willing to give up a portion of their freedom in order to be safe from murderers?

- Admittedly, these are not real-world situations, but the underlying ideas resonate in the post-September 11 era, when the security/freedom tradeoff has become a often-discussed topic.

- a roller coaster in which the loop-the-loops are philosophical as well as visceral.

- it nails the basic premise and some quintessential Dickian motifs

- Would you surrender a slew of civil liberties for a world without crime? Assuming that the right people were always jailed for the right reasons, I'd think about it long and hard.

- The idea that an individual could have a hidden life that even he doesn't know about is pure Dick, and it gives the suspense an extra kink

- Unlike the heroes of most blockbuster thrillers, Anderton isn't simply running away from special effects; he's running toward his future. He's trying to learn the identity of the man he's fated to murder - to prove that he won't commit the crime, that with knowledge he can change the future (...), no one's actions are predestined. 
- Whose idea was it to turn Minority Report into a mushy declaration of humanism?

- Cinematographer Janusz Kaminski ("Schindler's List") creates a powerfully simple landscape of icy blues and greys, a sleek yet bleak backdrop for the philosophical musings

- Minority Report es cine social en estado puro

- llama la atención que el complejo sistema articulado para ello paradójicamente dependa en el fondo no de aspectos técnicos, sino de elementos humanos y paranormales: las facultades adivi-natorias de tres mutantes denominados pre-cogs

- Así, apa-recen de soslayo reflexiones interesantes: una visión del futuro a lo George Orwell, dominada además por la publicidad; la ambigua mo-ralidad de un sistema que condena por crímenes no cometidos aún; la eterna duda razonable sobre la infalibilidad del sistema; o la traslúcida frontera tras el 11 de septiembre entre la lucha contra el crimen y la protección de los derechos individuales, y es que se nos muestra un futuro lejano en lo tecnológico, pero me temo que cercano en lo ideológico

- Los adelantos expuestos por Spielberg permiten la comodidad de los ciudadanos en sus vidas diarias, pero también eliminan su individualidad, fagocitada por una sociedad consumista que, a pesar de los progresos, todavía se muestra dividida en dis-tantes clases sociales

- describir la opresión de un individuo engullido por su tramposo entorno, de una sociedad que ahoga sus penas en el aparente confort de sus hábitos cotidianos. 
- su nueva situación familiar y sencillamente la experiencia que ha ad-quirido lo han convertido en una persona distinta, cuya ideología y concepto del mundo no le permitirían interpretar de la misma ma-nera los temas que se tocan en "Encuentros Cercanos..."

- atisbos de comentario social y discusión filosófica que podrían haber sido fascinantes pero que quedaron casi ocultos

Comentarios sobre la emoción (6)

- The world of the film represents a highly credible extension of the one we know, with life still dominated by personal emotions and work

- we have a haunted and embittered cop who uses drugs to escape his emotional pain.

- y ca-yendo en sensiblerías

-tal vez por eso las recientes películas de Spielberg han dejado tanto que desear, al menos en el terreno emocional

- resonancia emocional

Comentarios con referencia al héroe (4)

- Anderton is deeply motivated to save others from the same sort of tragedy that he himself experienced with a loved one -- a point the film drives home. 
- Anderton is on the job because his son was murdered, and he wants to prevent other people from having to endure a pain similar to his own.

- The hero, Anderton, doesn't have to think too hard. He has a vigilante's worldview and a fanatical loyalty to Precrime director Lamar Burgess (Max von Sydow).

- The film is consistently thrilling, if a little over-explanatory towards the end, and is given its human side largely by an authentic performance from Cruise

Comentarios negativos (9) frente positivos (34)

- you could require some pretty hefty winches and pulleys to get what may be a heavy load of incredulity off the ground

- Characters and the characterisation, however, fade into the background.

- Lo peor: que corra el riesgo de ser tan incomprendida por crítica y público como A.I. Inteligencia Artificial.

- guión que ya llegaba algo justito de fuerzas, y que en la última media hora me resulta en exceso forzado y tramposo, perdiendo credibilidad y frescura

- el guión se queda en la corteza, y ape-nas araña vagamente y sin profundidad la superficie de to-dos esos temas, desperdiciando la oportunidad de haber ido más allá del thriller futurista y hacer una gran película

- Spielberg ha jugado a hacer su propio “Blade Run-ner”... y ahí, tengo que decir que la empresa le ha quedado grande 
- contiene pasajes que, por su aparente intrascendencia, resultarán prescindibles para buena parte del público, que no conectará con las pretensiones del realizador.

- "Sentencia Previa" podría haber sido una profunda pelícu-la de ciencia ficción seria, en la que se hubieran cuestionado el destino inmutable o el libre albedrío como conductores de la huma-nidad, a la vez que se examinaba el flujo del tiempo y su naturaleza misma. Pero en vez de todo eso tenemos un típico espectáculo fílmico

- Esto reduce mucho el impacto de la cinta, pues en vez de ver personajes humanos bien realizados reac-cionando a situaciones extraordinarias, vemos tan sólo a los acto-res que dicen sus líneas y se comportan según lo dicta el guión

Comentarios positivos (34)

- "Minority Report" offers the most persuasively detailed portrait modern Hollywood has created of what the United States may look like 50 years hence

- Superbly handled 15-minute opening sequence grabs the viewer

- From intellectual conception to technical execution of the tiniest detail

- Janusz Kaminski, pic has a virtually seamless look in which many layers of visual elements have been superbly combined

- Alex McDowell's protean production design (...) is meant to reprep the latest in design and construction techniques some 40-50 years hence. Deborah L. Scott's costume creations are attractive (...), and John Williams supplies an energetically supportive score. 
- Samantha Morton, who plays one of the three Pre-Cogs, is confined to lying in a pool for a good stretch but brings a terrific physical intensity to her unique role when she is finally liberated and is central to one of the most memorable scenes in the picture

- Von Sydow has the perfect voice of authority as the "father of Pre-Crime," and the many small supporting roles have for the most part been expertly filled

- Here is the movie Steven Spielberg should have made instead of AI

- As for Spielberg, it is a treat to be in the hands of a director who can deliver such a substantial, ambitious and high-IQ piece of entertainment

- Steven Spielberg's Minority Report is, by turns, amazing, thrilling and puzzling, but it is also utterly devoid of humour

- Minority Report is undeniably a visual feast

- The textures and depth, the surfeit of surfaces and the grainy tangibility of the atmospheres they create are what make Minority Report a work of art

- to applaud the arrival of something like Minority Report.

- The whodunnit? and whydunnit? elements are as intricately explored and satisfyingly resolved as those in any of the cinema's great noir classics.

- Action fans have plenty to engage their attention. Minority Report features its share of shoot-outs, fights, and chase scenes, some of which are quite spectacular. 
- The choice of Tom Cruise as Anderton is a case of perfect casting

- Anderton is an active individual, but he's not a superman, and he is a better developed character than Cruise's Mission: Impossible alter-ego.

- However, this is not just a "rebound" picture; it's an achievement - arguably the best escapist entertainment the director has produced in two decades.

- Steven Spielberg's Minority Report (DreamWorks/20th Century Fox) is even greater than the sum of its parts

- I must admit that I find elements of this future attractive

- It has been a long time since a Spielberg film felt so nimble, so unfettered, so free of self-cannibalizing

- he really is one of the most wittily dexterous filmmakers alive, and he gets a fine, focused performance from Cruise, who's better when you can't spot him acting

- This script is so smart and the editing (by Michael Kahn) so crackerjack that every freaky black-comic element works like gangbusters

- Minority Report es una montaña rusa de ideas que se multiplica en mil y un vectores cuyo punto de fuga es el genio sin límites

- Spielberg, como Hitchcock (y, por qué no, como Kubrick), es el gran demiurgo, el experimentado maestro de marionetas que hace juegos malabares con la muerte futura. 
- Lo mejor: la arrolladora secuencia inicial.

- "Minority Report", la última obra de uno de los mayores genios del cine contemporáneo

- no puedo hacer otra cosa que rendirme ante el subyu-gante decorado en el que ésta se de-sarrolla, discurriendo a través de vi-brantes pasajes de acción y emocionantes fragmentos de incertidumbre

- La calidad de "Minority Report" no se centra en su guión, sino en la fastuosa puesta en escena de Steven Spielberg y su equipo.

- secuencias de una abru-madora fortaleza técnica

- el Rey Midas de Hollywood es, además de todo lo dicho en los anteriores párrafos, un gran director de actores.

- de "Star Wars. Episodio II. El Ataque de los Clones", siendo su aportación verdaderamente memorable en los pasajes más intimistas de la historia

- "Minority Report" es, en definitiva, un trabajo de apreciable belle-za, sorprendente, extraño (atención a algunos de los personajes que pululan por la historia) e incluso fascinante

Atrápame si puedes

Comentarios con relación a la dignidad de la persona (15) 
- It may be morally lazy to say that we like Frank because he's scamming banks and hotels and corporations instead of bilking old ladies out of their Social Security checks.

- But of all the amoral temptations the movie throws in our path, thievery is the hardest to resist, especially when it lets us live out our dreams of a lush life.

- He and screenwriter Nathanson turn Frank into another of Spielberg's lonely, misunderstood kids, running away from the pain of a broken home, living out the dreams his beloved, hapless father couldn't realize.

- Christopher Walken plays dad with more than his usual mischief, with a warmth and vulnerability.

- Frank to Carl and explores the nature of their peculiar long-distance relationship. That's probably inevitable because "Catch Me if You Can" is as much about the participants as it is about the chase

- "Catch Me If You Can" (not the most inspired title in the world) follows this story as a lighthearted yarn, a fairy tale in which you find yourself rooting for someone who makes a point of deceiving people.

- it's a coming of age story, and then very much a family drama.

- ya iba siendo hora de que algunos auto-res se atrevieran a desmitificar una forma de vivir que, si para unos es sinónimo de rebeldía frente a un sis-tema que consideran injusto, para otros no es más que una manera de lucrarse a costa de las libertades ajenas. 
- delinquir no dependía tanto de la técnica o de la informática, sino del carisma de una buena actuación y de la habilidad para engañar a los demás valiéndose de ella

- Tom Hanks, que ya no necesita demostrar lo gran actor que es, da vida a un personaje en principio antipático, un hombre cualquiera que se obsesiona con dar caza al joven trapisondista y que, empero, también esconde una historia que le hace contemplar lo que le rodea con cierta desgana.

- la propia fami-ia de Abagnale una explicación a su comportamiento, como si en realidad el chico burlara la ley a modo de travesura, de juego inma-duro, para suplir o huir de sus carencias afectivas, porque no con-taba con unos referentes paternos de férrea moral.

- Spielberg repite los mismos errores tácticos que se le suelen atribuir en estos casos: esa defensa de la familia norteamericana unida como base de la formación de un individuo íntegro y honrado, y, sobre todo, esa sordera sentimental que acusa siempre a la hora de transmitir emociones y que le empuja a caer en la obviedad.

- Resulta paradójico que la única persona capaz de valorar su habilidad y de comprender sus actos

- admiración de Hanratty por Abagnale se acaba tornando en una especie de afecto distante, de complicidad inconfesable, y lo mismo se puede decir sobre lo que siente Abagnale respecto el po-licía.

- el porqué este mozalbete encantador, bien vestido, físicamente atractivo, aseado, conseguía salirse con la su-ya.

Comentarios sobre la emoción (3) 
- el espectador tan pronto suelta una espontánea carcajada cuando el protagonista se hace pasar por un profesor de francés como queda emocionalmente afectado al observar la desesperación de Frank

- el autor predilecto de Spielberg resume con sus notas las emociones que desprende la película

- que al Spielberg trascendental, porque su madurez emocional

Comentarios con referencia al héroe (20)

- Si los comentarios hacen mucha referencia a Frank puedo buscar la fuerza de este personaje en su habilidad y en el hecho de que es de carne y hueso.

- Young Frank is a crooked version of one of the boy dreamers and adventurers who've long populated Spielberg's movies

- His impersonation of a pilot, and later a doctor and a lawyer, are simply a kid's version of dress-up taken too far

- he wants them to like him, and he basks in their adoration.

- A wild kid who's in love with the appearance of things

- "Catch Me If You Can" check forging becomes just a young man's dramatic response to his parents' divorce

- Spielberg allows us to buy this by lavishing time on young Frank's relationship with his father, who, like his son, is theatrical and has a touch of larceny 
- He embarks on a life of cheating, not for the psychological joy of deceiving people, but for survival. And he's good at it.

- "You always said an honest man has nothing to fear," he writes in one of many letters to his father as he starts out. "So I'm trying my best not to be afraid."

- What makes Frank so appealing, apart from DiCaprio's charms, is the less-thanappealing person chasing him. Hanratty spends his life at the office, unreasonably fixated on getting the kid

- Hanratty literally has Frank cornered when the teenager turns the tables with a sublime act of deception. He escapes the FBI agent in plain sight. And that's the Peter Pan secret too.

- Frank's audacious style saved him several times

- Frank's father (Christopher Walken) was his role model, even though his parents split up

- Le héros de ce récit rocambolesque mène une existence falsifiée, source d'un bonheur fragile et fabriqué qu'il protège en fuyant constamment la réalité

- Di Caprio, tras el divorcio de sus padres, se adentra en un mundo de ensoñación en el que todo le sale bien, en una irrealidad creada por él mismo para no enfrentarse al drama familiar que le acecha.

- Así, protagoniza una huída constante de la vida real, un juego cuyo premio es la vuelta al pasado de una hogar feliz. En el fondo, Leo es, ante todo, un chico que busca el calor familiar, de un padre o una madre 
- De esta manera, el personaje de Hanks se convierte en indispensable al transformarse de un simple policía en un padre que quiere "ayudar" a un hijo

-Di Caprio, ya trabajando en el FBI, está a punto de volver a escaparse. ¿Por qué? Para volver a sentir que alguien piensa en él, que Hanks está detrás de él... "Pero ya nadie te persigue", le recuerda el agente del FBI

- La película se sustenta en los sólidos pilares de una historia de dos personas reales, impresionantemente interpretadas por Hanks y Di Caprio

- este muchacho ha elegido un camino de huida y soledad (la ruptura de su familia y la influencia de su padre tienen mucho que ver en ello) y cómo es capaz de mantenerlo a pesar de ser continuamente perseguido por el FBI.

- Frank acabará incluso invo-lucrando a terceras personas (caso de Brenda, a la que propondrá matrimonio).

Comentarios negativos (7) frente positivos (18)

- The decision to go with it as comedy shuts out some of the more interesting explorations of the character, robs the film of its promised tension (...) reducing the man to a freak

- You can see the problem: too much pigeon-hole-ing into genres and styles, instead of paying attention to the character and the story.

- Spielberg y trace avec un heureux mélange d'humour et d'empathie le portrait nuancé d'un jeune homme, blessé sur le plan émotif, qui se cherche en se réinventant constamment. 
- Spielberg en un año tras "Inteligencia Artificial" (desastrosos últimos veinte minutos que estropean toda la película por su obligado y ñoño final feliz)

- Película simpática, elegante, fluida, aunque irregular

- Prefiero a este Spielberg ocioso y despreocupado

- No es éste, desde luego, el mejor trabajo de Spielberg, y no creo que ésa fuera la ambición de su autor

Comentarios positivos (18)

- it's at least a step in the right direction, away from portentous spectacle and towards something resembling light, loose-limbed entertainment.

- Catch is a cinematic soufflé, as buoyant as his previous two films

- Fans of longtime Spielberg collaborator John Williams will enjoy "Scoring Catch Me If You Can," which shows how the composer forwent his usual orchestral bombast for a '60s-style jazzy soundtrack

- "Catch Me If You Can" is an ode to con games and larcenous behavior

- "Catch Me if You Can" is 140 minutes of fun. It may have moments of seriousness that are effective, and relationships that are presented with depth and sincerity that add to our enjoyment.

- he casts off solemnity in "Catch Me if You Can" and gives us -- not his best movie -- but one of his smoothest and maybe his friendliest. The colorful cinematography, 
smart performances and brisk tempo suggest a filmmaker subordinating every other impulse to the task of manufacturing pleasure

- Spielberg has fun re-creating this and other aspects of mid-'60s America

- "CATCH ME If You Can" is a movie that steadfastly refuses to be spectacular. At first, that seems to be its drawback. In the end, that's its disarming sweetness

- As soon as you get over Spielberg's light touch, you can enjoy a pleasant, mildly diverting story based on the life of Frank Abagnale Jr., a con artist to remember.

- the film is intermittently engaging and fun

- Mais qu'on ne s'y trompe pas, pour drôle et pétulante que soit cette comédie aux délicieux coloris pastels, elle n'a rien d'insignifiant

- "Minority Report" (fabulosa en todos los sentidos), reencuentra al director con un tipo de cine más humano que había abandonado desde "La lista de Schiendler"

- Comedia y drama se aúnan habilidosamente para for-mar un cohesionado conjunto en el que las risas y los llantos se suceden de forma intermitente

- una entretenidísima obra que, a pesar de sus trage-dias, porque toda existencia las tiene, deviene en una apa-sionada oda al disfrute de la vida

- Williams aporta a la cinta una jazzística partitura con la que imprime al montaje la presteza que precisa 
- su pre-sencia sirve para redondear una obra que pasará a formar parte de los mejores trabajos del creador de E.T

- Película simpática, elegante, fluida

- A quienes el año pasado disfrutaron con un Spielberg más denso, oscuro, metafísico, circunspecto...

\section{La Terminal}

Comentarios con relación a la dignidad de la persona (18)

- observes the terminal as a home to an entire community of uprooted persons

- she finds herself drawn to Viktor's honesty and warmth

- Spielberg marshals his cast of lovable ethnic stereotypes with a kind of benevolent glow that suggests he feels he's doing them all an immense favour

- figure that these brand names induce a happy, familiar shopper-daze in the cinema auditorium?

- It's a familiar subject,

- Eventually he can afford a Hugo Boss suit (part of the film's relentless product placement) in which to court a beautiful air hostess (Catherine Zeta-Jones), whose confidence in human goodness he's helping to restore 
- the prospect of Spielberg making a whole film in a terminal, exploring it top to bottom as a kind of ecosystem through the eyes of a non-English-speaker who's marooned, seemed too good to be true

- turning Zeta-Jones' character into a self-help cliché right out of Smart Women, Foolish Choices

- a warm, neurotic, available, troubled woman who, above all, is unaccountably attracted to the humble hero

- In his case, he just refuses to leave. Spielberg eschews that possibility -- that would make Viktor a little nutty

- E.T. is precisely what Viktor turns into -- a wise, kind, benevolent alien who eventually has to go home, but in the meantime is all about sharing the love

- Spielberg estaba empezando a madurar en su cine asuntos tan serios como cierto pesimismo existencial so-bre la forma en la que el ser humano manifiesta su capacidad y su necesidad de amar (enfoque de lo más kubrickiano que impregna-ba gran parte del metraje de "A.I. Inteligencia artificial")o como el trauma de una trágica desaparición ("Minority report") o el derrumbe de la seguridad que ofrecía una unidad familiar ("Atrápame si pue-des") motivaba los actos de sus protagonistas, siempre a la bús-queda inútil de un equilibrio perdido para siempre o en perpetua hui-da hacia ninguna parte.

- "La ter-minal" es en cierto modo su contribu-ción a equilibrar un poco las cosas en un mundo que va de mal en peor des-de los hechos del 11-S. 
- una fábula vital y humanista, un canto optimista a la bondad intrínseca del ser humano, un film que, a la manera de aquellas pelí-culas que Frank Capra y James Ste-wart hacían en los años 40 y 50,(...) hay que seguir confiando en la ca-pacidad del ser humano para sobreponerse a la desgracia y salir adelante con la ayuda de nuestros semejantes

- todo puede supe-rarse en América si hay solidaridad y buena voluntad.

- Spielberg intenta huma-nizar con su relato esa construcción en la que se ocultan realida-des que permanecen escondidas en las mentes de sus dueños.

- "La terminal" es una reafirmación de la individualidad positiva del hombre, la misma que en ocasio-nes consigue que no seamos fago-citados por las peores caracterís-ticas que conforman una socie-dad

- "La terminal" se convierte, pues, en una representación de la confianza en el ser humano, ca-paz de acometer las mayores atrocidades, cierto, pero también de destapar los valores y los principios que de alguna forma guarda en su corazón.

- It's the terminal's part-time residents who could use a helping hand

- Comentarios sobre la emoción (4)

- is played by someone as sympathetic as Hanks, a gifted comedian who can manage guile but hasn't a streak of nastiness in him

- But the movie is heading steadily into Capraesque sentimentality

- Viktor's situation carries significant emotional weight 
- aunque es evidente que hace un esfuerzo para no pro-vocar la emotividad del espectador

Comentarios con referencia al héroe (18)

- He can't fly back and he can't enter the United States. He is "unacceptable."

- Viktor's self-consciousness and near- panic every time he has to ask anyone for anything.(...) It's a feeling of complete dislocation and vulnerability.

- peripecia vital de Viktor Navorski, un viajero (...) atrapado en una situación de alegalidad en la zona de tránsito internacional del aeropuerto JFK de Nueva York y al que no le queda más opción que apañárselas para sobrevivir allí

- Tom Hanks, capaz de hacer de su despistado turista (que comienza siendo algo así como el primo eslavo de Forrest Gump) un personaje tan entra-ñable como inteligente, con una admirable capacidad de adapta-ción y una humanidad a prueba de bombas.

- cualquier ciudadano puede en un momento de-terminado ser víctima de una jugarreta del destino como la que sufre el per-sonaje encarnado por Tom Hanks

- Viktor va solucionando sus primeros obstáculos, que a veces nos hacen pensar en las curiosas situaciones a las que se veían abocados los personajes de Jacques Tati en obras como "Playtime", gracias a su inteligencia, su tenacidad y, por supuesto, a la complicidad de los trabajadores de la Terminal 
- esta historia de soli-daridad y buen rollo que se establece entre el protagonista y los americanos que lo rodean y acogen, precisamente en uno de los aeropuertos más desa-gradables, inhóspitos y de más difícil acceso para los extranjeros

- Navorski es un tipo que, a pesar de la adversidad que le circunda, ja-más dejará de ser él mismo. Su lucha contra la burocracia o la indiferencia de sus semejantes será constante y tenaz. Su individualismo no es egoís-ta, pues no ve en el resto de la gente un objetivo a batir (todo lo contrario de lo que le sucede al responsable del aeropuerto, Dixon), sino un bálsamo que sirve de ejemplo a una masa adormecida a causa de la rutina

- A midair coup has turned Viktor's homeland into a nonentity, leaving him, as security chief Frank Dixon (Stanley Tucci) puts it, "a citizen of nowhere."

- Viktor does as he's told. He waits. Confined to the "international lounge," Viktor builds himself a home at a disused gate, but spends his days (and most of the movie) roaming between the chain stores that make up the airport's massive, sunlit mall.

- But Viktor's ultimate goal isn't assimilation - like one of Spielberg's past protagonists, he only wants to go home

- Dixon urges him to claim asylum, but Viktor refuses even to feign fear of his homeland. "I no afraid Krakhozia"

- Viktor has fallen through a "crack" in the system, but the man from crack-ozia is used to living between the lines

- there's something slightly inhuman about the fact that he never becomes bitter or enraged 
- He's a caricature of the perfect immigrant: He's hardworking, self-sufficient and doesn't ask too many questions

- Viktor begins to set up a life for himself, getting to know the people who work in the terminal and developing an interest in a pretty stewardess, Amelia (Catherine Zeta-Jones), who comes across his path on more than one occasion.

- Viktor gradually adapts to life in the airport - much to the growing anger of the rabidly ambitious Dixon

- with Hanks once again figuring out how to eat, where to sleep and how to amuse himself in an inhospitable environment

- Viktor's most magical talents, though, are reserved for Amelia (Catherine ZetaJones), a harried flight attendant with a checkered romantic history

- Víctor, pese a ser todo bondad y buena voluntad, necesi-ta de la amabilidad de los extraños, de la ayuda de ese melting pot característico de los USA para sobrevivir primero y progresar des-pués.

Comentarios negativos (11) frente a positivos (17)

- Though relatively minor compared to his superb work on the new "Harry Potter" pic, John Williams' score still offers an enjoyable coupling of typically Holst-ian fanfares and more adventurous, klezmer-influenced riffs

- Steven Spielberg gives us his inimitably cutesy take on airport paranoia and homeland security 
- and the film's success derives from the "small moments" and details

- The Terminal is probably the least entertaining film Spielberg has made since the sappy clunker Always (1989).

- Even in this sub-par film, the actor is impressive; a movie star to the core and terrifically versatile.

- In "The Terminal," Steven Spielberg has made an ineffably appealing and rather sweet film about a guy who gets stuck in an airport

- But first take a minute to admire a filmmaker who can transform a potentially static premise into a movie that's one long succession of interesting, detailed and amusing moments.

- With great filmmakers, the whole movie is happening every second

- Along with Spielberg, screenwriters Jeff Nathanson, Sacha Gervasi and Andrew Niccol somehow found a way to create a sense of forward motion, through what easily could have seemed like a succession of disparate incidents.

- The romance is appealing, but it also exists on the movie's fault line, the one between truth and fable

- It's a strange thing to realize: Spielberg never adequately accounts for why Viktor must stay in that airport for months. Instead, he uses his cinematic fairy dust to make us stop asking the question 
- But Spielberg won't go too far with that, either, because he wants to keep everybody within the realm of cuddly

- Steven Spielberg utiliza con habilidad el decorado en el que acontece la narración

- Aunque en "La terminal" Tom Hanks recupera con tino la comici-dad que le dio a conocer, lo hace de manera contenida y mezclán-dola con sus estupendas dotes dramáticas

- John Williams construye una fina partitu-ra que aparece en puntuales momentos del relato, captando el compositor con su música el carácter del protagonista.

- Each lit-up Starbucks sign is like a beacon guiding Viktor into the rocks, a cruel reminder of the world he can't access.

- ought to be applauded, not denigrated, especially because he doesn't feel the reflexive need to go low-budget to demonstrate his seriousness

\section{Comentarios negativos (11)}

- In The Terminal, however, those "big moments" betray Spielberg more often than not

- His first mistake is to force-feed us a villain.

- he is turned into a hero through an incident that hardly merits canonization

- one of the subplots is left frustratingly unresolved 
- it's the uncertain tone, tepid banter, and poorly developed characters that finally derail The Terminal

- The Terminal is the third and weakest film Tom Hanks has made with Spielberg

- probablemente es el trabajo menos intere-sante y logrado de Spielberg en los últimos años

- Incredulidad a la que ayudan histo-rias introducidas con calzador como la del inmigrante ruso retenido, la re-solución del romance (?) entre el lim-piador y la oficial de inmigración o la revelación del delirante motivo del via-je de Viktor a New York

- Hay que reconocer, no obstante, que a la película le sobra metraje y que a veces cae en una molesta irregularidad.

- ought to be applauded, not denigrated, especially because he doesn't feel the reflexive need to go low-budget to demonstrate his seriousness

- (The Terminal) is and a failed social comment.

Volver a los comentarios de los críticos Volver al Anexo I Volver al principio del articulo Volver al comienzo

Anexo II: lista de presupuesto y recaudación de taquilla de la filmografía spielbergiana. Presupuesto y ganancia en taquilla en EE.UU. (datos tomados de $\mathrm{IMDb}$ ) de la filmografía de Steven Spielberg. Hay más ganancias en todo el mundo, de ventas de videos y DVD familiares, y beneficios de merchandising que no se tendrá en cuenta. 
1. El diablo sobre ruedas (1971)

Presupuesto (estimado) 450.000 dólares

2. Loca evasión (1974)

Presupuesto (estimado) 3.000.000 dólares

Grueso de recaudación en taquilla 7.500.000 dólares en EEUU

3. Tiburón (1975)

Presupuesto (estimado) 12.000.000 dólares

Grueso de recaudación en taquilla 260.000.000 dólares en EEUU

4. Encuentros en la tercera fase (1977)

Presupuesto (estimado) 20.000.000 dólares

Grueso de recaudación en taquilla 132.088.635 dólares en EEUU

$5.1941(1979)$

Presupuesto (estimado) 35.000.000 dólares

Grueso de recaudación 31.755.742 dólares en EEUU en taquilla, pero sobrepasa el presupuesto si tenemos en cuenta las otras recaudaciones: 92.455 .742 por todo el mundo y 60.700 .000 no en EEUU) 
6. En busca del Arca Perdida (1981)

Presupuesto (estimado) 20.000.000 dólares

Grueso de recaudación 242.374.454 dólares en EEUU en taquilla

7. E.T. el Extraterrestre (1982)

Presupuesto (estimado) 10.500.000 dólares

Grueso de recaudación 435.110.554 dólares en EEUU en taquilla (estimación hasta mayo del 2002). Las cifras de recaudación son muy altas, por ejemplo, en todo el mundo 756.700 .000 dólares.

8. Indiana Jones y el templo maldito (1984)

Presupuesto (estimado) 28.000.000 dólares en EEUU

Grueso de recaudación en taquilla 179.870.271 dólares

9. El color púrpura (1985)

Presupuesto (estimado) 15.000.000 dólares

Grueso de recaudación en taquilla 94.175.854 dólares en EEUU

10. El imperio del sol (1987) 
Presupuesto (estimado) 38.000.000 dólares

Grueso de recaudación 22.238.696 dólares en EEUU en taquilla (el otro dato que da es la recaudación de Suecia de 7.027.453, aún así pensamos que habrá recaudado por lo menos el presupuesto en todo el mundo).

11. Para siempre (1989)

Presupuesto (estimado) 29.500,000 dólares

Grueso de recaudación en taquilla 43.858.790 dólares en EEUU

12. Indiana Jones y la última Cruzada (1989)

Presupuesto (estimado) 48.000.000 dólares

Grueso de recaudación en taquilla 197.171.806 dólares en EEUU

13. Hook (1991)

Presupuesto (estimado) 70.000.000 dólares

Grueso de recaudación en taquilla 119.654.900 dólares en EEUU

14. Parque Jurásico (1993)

Presupuesto (estimado) 63.000.000 dólares

Grueso de recaudación en taquilla 357.067.967 dólares 
15. La lista de Schindler (1993)

Presupuesto (estimado) 25.000.000 dólares

Grueso de recaudación en taquilla 96.067.179 dólares en EEUU

16. El mundo perdido: Jurassic Park (1997)

Presupuesto (estimado) 73.000.000 dólares

Grueso de recaudación en taquilla 229.074.524 dólares en EEUU (estimación del 12 octubre 1997)

17. Amistad (1997)

Presupuesto (estimado) 40.000.000 dólares

Grueso de recaudación en taquilla 44.175.394 dólares en EEUU (estimación del 5 de abril de 1998)

18. Salvar al soldado Ryan (1998)

Presupuesto (estimado) 70.000.000 dólares

Grueso de recaudación en taquilla en EEUU 216.119.491 dólares (estimación del 23 mayo 1999)

19. Inteligencia Artificial (2001) 
Presupuesto (estimado) 90.000.000 dólares

Grueso de recaudación en taquilla en EEUU 78.616.689 dólares (estimación del 23 de septiembre del 2001)

20. Atrápame si puedes (2002)

Presupuesto (estimado) 52.000.000 dólares

Grueso de recaudación en taquilla en EEUU 164.435.221 dólares

21. Minority Report (2002)

Presupuesto 102.000.000 dólares

Grueso de recaudación en taquilla en EEUU 132.014.125 dólares (27 de octubre del 2002)

22. La Terminal (2004)

Presupuesto (estimado) 60.000.000 dólares

Grueso de recaudación en taquilla en EEUU 77.032.279 dólares

23. La guerra de los mundos (2005)

Presupuesto 132.000.000 dólares 
Grueso de recaudación en taquilla en EEUU 234.280.354 dólares (22 de noviembre del 2005)

24. Munich (2006)

Presupuesto 75.000.000 dólares

Grueso de recaudación en taquilla en EEUU 47.113.190 dólares (12 de marzo del 2006) 